\title{
Hva bør non-inferiority-studier kalles på norsk?
}

\author{
Studier der man skal finne ut om et legemiddel ikke er dårligere enn et annet - det vil si ikke underlegent - \\ kalles på engelsk non-inferiority studies. De bør på norsk kalles ikke-underlegenhetsstudier. Vi mener dette \\ vil bidra til å lette forståelsen og få bort mystifiseringen av slike studier.
}

Kliniske studier kan være designet for å vise at et legemiddel er bedre enn placebo eller et annet legemiddel. I mange situasjoner er det imidlertid mer aktuelt å vise at en legemiddelbehandling (eller tiltak eller prosedyre) ikke er dårligere enn en annen, ofte gjeldende standardbehandling. Studier som skal vise at det er slik, kalles på engelsk non-inferiority studies (eller trials) $(1,2)$.

Første gang begrepet non-inferiority er registrert brukt i PubMed, er så sent som 1998 (3). I Tidsskriftet er det brukt på ulike måter fire ganger, første gang i 2003 (4-7). Hjelmesæth \& Røislien skrev i 2007 at denne typen studier har flere begrensninger og påpeker at resultatene fra en perfekt utført studie med slik design ikke alltid oppfattes som like solide som dem fra studier som er designet for å vise at en behandling er bedre enn en annen (5).

\section{Omstridt og fremmed}

Vårt inntrykk er at mange leger ikke er fortrolig med begrepet non-inferiority studies, og at det er mange som misforstår hvordan slike studier skal tolkes. Vi tror den engelske språkformen bidrar til at begrepet virker fremmed og vanskelig. Etter vår mening vil et godt avløserord på norsk, dvs. en oversettelse, gjøre det lettere å forstå hva slike studier dreier seg om.

Man skiller gjerne mellom tre former

for kliniske studier $(1,2)$ :

- Studier som skal vise at en prosedyre er mer effektiv enn en annen (kalles på engelsk gjerne superiority studies)

- Studier som skal vise at en prosedyre ikke er vesentlig mindre effektiv enn en annen (non-inferiority studies)

- Studier som skal vise at en prosedyre er like effektiv som en annen (equivalence studies)

For dem som søker en mer inngående drøfting av forskjellen mellom slike studier, henviser vi til andre kilder $(1,2)$. Populært sagt kan man si at det er en forskjell mellom «å være like god som» og «ikke å være dårligere enn». Forskjellen kan virke liten, men den kan være viktig.

Non-inferiority-studier er altså ikke det samme som ekvivalensstudier. Dermed kan ikke ordene ekvivalensstudier eller likeverdighetsstudier brukes som norsk oversettelse av non-inferiority studies.

\section{Enkle oversettelser}

Det synes å være en utbredt oppfatning at uttrykket non-inferiority studies er vanskelig å oversette (1). Vi er ikke enige. Det er faktisk veldig lett. Prefikset non- kan byttes ut med prefikset ikke-, og inferiority kan rett og slett oversettes med underlegenhet (8) - mindre aktuelt i denne sammenheng er mindreverdig og inferiør (9). Da gir oversettelsen av non-inferiority studies seg selv: ikke-underlegenhetsstudier.

Ordet er litt langt og kan med det samme virke noe fremmed og konstruert, men det gjør antakelig også non-inferiority for dem som har engelsk som morsmål. Vi tror ordet vil sette seg etter en tilvenningsperiode.

Det er nærmest selvforklarende og kan etter vårt skjønn bidra til å svekke den mystifiseringen som denne type studier har vært omgitt med.

Hva så med superiority studies og equivalence studies? Også her gir oversettelsene seg selv: overlegenhetsstudier og ekvivalensstudier.

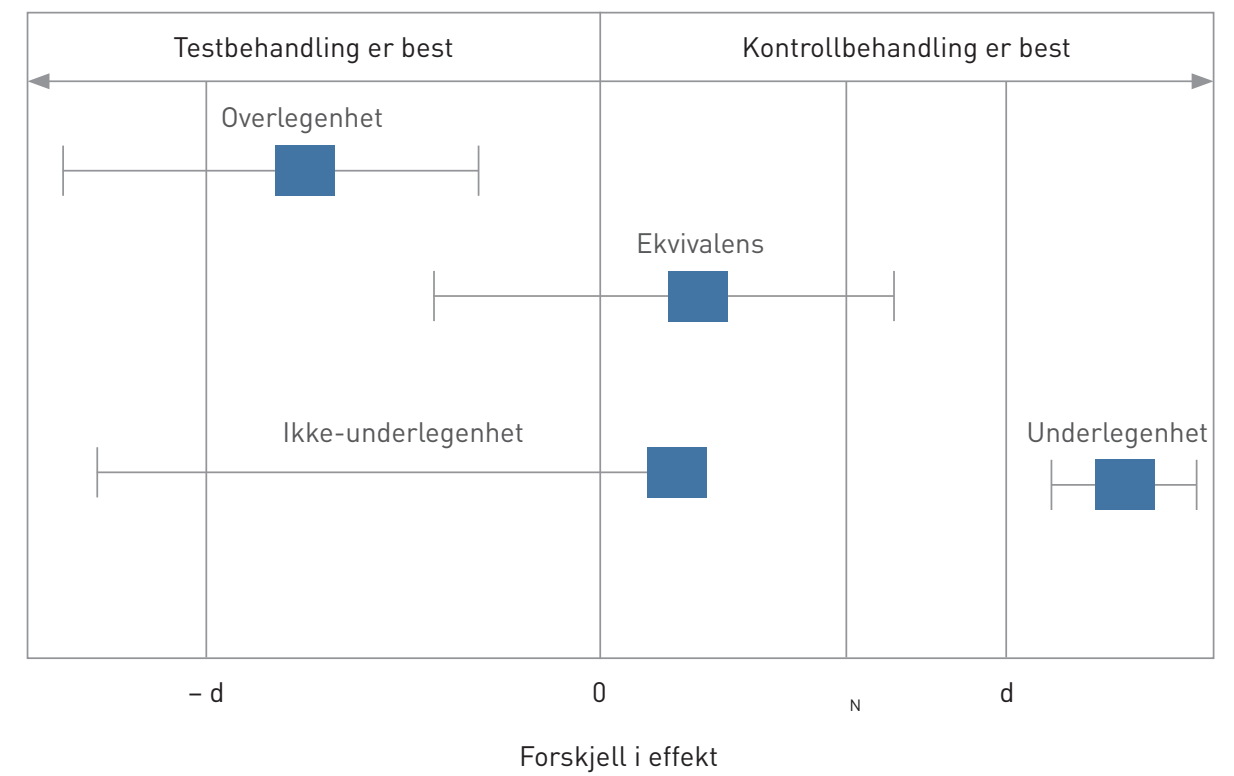

Figur 1 Skjematisk fremstilling av forskjellene mellom ulik studiedesign ved kliniske intervensjonsstudier. Figuren angir punktestimater og konfidensintervaller for forskjell i effekt mellom testbehandling og kontrollbehandling. Intervallet mellom -d og d angir ekvivalensspenn og $\Delta_{N}$ ekvivalensmargin 
Figur 1 gir en idé om forskjellene mellom studier som viser overlegenhet, ekvivalens, underlegenhet og ikke-underlegenhet.

\section{Petter Gjersvik}

petter.gjersvik@medisin.uio.no

Erlend Hem

Geir Wenberg Jacobsen

Michael Bretthauer

Petter Gjersvik (f. 1952) er medisinsk redaktør ¡ Tidsskriftet og førsteamanuensis ved Universitetet i Oslo.

Erlend Hem (f. 1970) er dr.med. og assisterende sjefredaktør i Tidsskriftet.

Geir Wenberg Jacobsen (f. 1945) er medisinsk redaktør i Tidsskriftet og professor i samfunnsmedisin ved Norges teknisk-naturvitenskapelige universitet.

Michael Bretthauer (f. 1969) er spesialist $\mathrm{i}$ indremedisin og professor ved Institutt for helse og samfunn, Universitetet i Oslo.

\section{Litteratur}

1. Skovlund E, Vatn M. «Non-inferiority»-studier.

I: Laake P, Olsen BR, Benestad HB, red. Forskning i medisin og biofag. 2. utg. Oslo: Gyldendal Akademisk, 2008: 276-9.

2. Skovlund E, Bretthauer M. Kliniske studier.

I: Laake P, Hjartåker A, Thelle DS et al. red. Epidemiologiske og kliniske forskningsmetoder. Oslo: Gyldendal Akademisk, 2007: 297.

3. Steinijans VW, Neuhäuser M, Hummel T et al. Asthma management: the challenge of equivalence. Int J Clin Pharmacol Ther 1998; 36: 117-25.

4. Lund H, Flaten O, Skattebøl A. Positivistisk legemiddelforskning. Tidsskr Nor Lægeforen 2003, 123: 2620.

5. Hjelmesaeth J, Røislien J. Rosiglitazon-statistikk til nytte og besvaer. Tidsskr Nor Lægeforen 2007; 127: 2702-3.

6. Hem E. Hvordan behandle plutselig hørselstap? Tidsskr Nor Legeforen 2011; 131: 1631.

7. Haug C. Hva skjedde med Dan Markingson? Tidsskr Nor Legeforen 2013; 133: 2443-4.

8. Engelsk stor ordbok. Oslo: Kunnskapsforlaget, 2001: 512. http://ordnett.no/search?drillPub= $19 \&$ search=inferiority (12.1.2014).

9. Bokmålsordboka. www.nob-ordbok.uio.no/perl/ ordbok.cgi?OPP=inferi\%C3\%B8r\&ordbok=begge (12.1.2014).

Mottatt 14.1. 2014 og godkjent 18.3. 2014. Redaktør: Marit Fjellhaug Nylund. 